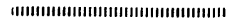

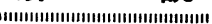

\section{超高圧を用いる有機合成}

中田忠

理化学研究所有機合成化学研究室

(平成 5 年 5 月 20 日受理)

\title{
Organic Synthesis under High Pressure
}

\author{
Tadashi Nakata \\ Synthetic Organic Chemistry Laboratory, The Institute of Physical and \\ Chemical Research (RIKEN), Hirosawa, Wako 351-01, Japan
}

\section{は じめに}

近年の有機合成化学の発展は目覚むしいものがあり, これまで合成困難であった複雑な化学構造をもつ天然有 機化合物の合成も可能になってきている．これら天然物 を選択的かつ効率的に合成するために，優れた有用化学 反応の開発，合成手法の開発が常に要望されている．最 近，それら合成手法の一つとして超高圧がよく用いられ るようになってきた。

これまで化学反応が進行しない場合には，一般に熱, 光あるいは触媒等を用いることにより目的とする反応を 達成していた．しかし，いかに条件を設定しても，たと えば敩しい立体障害のために目的とする反応がまったく 進行しない場合がある。このようなきわめて進行困難な 反応でも超高圧という反応場では速やかに反応が進行す る可能性があり, 最近この分野の研究が注目を集めてい $る^{1)}$.

通常の化学反応に用いられる高圧力は, 接触還元など に用いられる数気圧から 100 気圧程度であるが，ここ でいう超高圧とは 1 万〜 万気圧 $(10 \sim 20 \mathrm{Kbar})$ とい う圧力でありこれは自然界の圧力と比較すると深海底 をはるかに越えた圧力に相当する．通常では進行困難な 反応もこのような圧力下におくと速やかに反応が進行す る場合がある.化学反応に用いられる圧力と自然界の圧 力との比較を図 1 に示した.

超高圧下における化学反応においては, 反応速度の加 速, 反応収率の向上が期待でき，またこれまで合成不可
能であった有用化合物，試蒋等を合成でき，あるいは通 常とは異なるユニークな反応が見いだされる可能性もあ り, 近い将来大きく発展することが期待されている.

\section{超高圧化学反応装置}

このような研究の前提となるのは超高圧化学反応装置 であるが，増幅型，直接型ピストンーシリンダー方式， マルチ型ピストンーシリンダー方式の反応装置などがあ る.一般的にはそれほど大容量の装置はなく，反応容量 $100 \mathrm{ml}$ 程度の装置が最大のものである. 国内にあって は反応容量 $1 \sim 5 \mathrm{ml}$ の増幅型の反応装置が市販されて おり，すでに数グループが本装置を用いて超高圧下での 化学反応の研究を展開している. 最近, 理化学研究所研 究基盤技術部では直接型ピストンーシリンダー方式の大 量合成可能な超高圧反応装置を設計，開発した，超高圧 反応容器, 超高圧圧力発生装置, 加圧制御装置, 温度制 御装置, テフロン製の反応チューブ $(0.2,1,5,10,30$, $50,150 \mathrm{ml}$ など各種) からなり，その性能はわれわれ 合成化学者の要求を満足させるものである(図 2,3 ). 現 在, $15 \mathrm{Kbar}-150 \mathrm{ml}, 20 \mathrm{Kbar}-50 \mathrm{ml}$ の反応生力-反 応容量を有する世界最高レベルの優れた反応装置の開発 に成功している.

本装置を用いて実際の超高圧反応は次のように行なわ れる. まず, 反応原料, 試薬, 反応溶媒を入れたテフロ ン製反応チューブを超高圧反応容器に入れ，そのまわり を圧力媒体 (ケロシンープロパノール) で浸す。これをピ ストンで押すことにより発生する圧力を，圧力媒体を通 


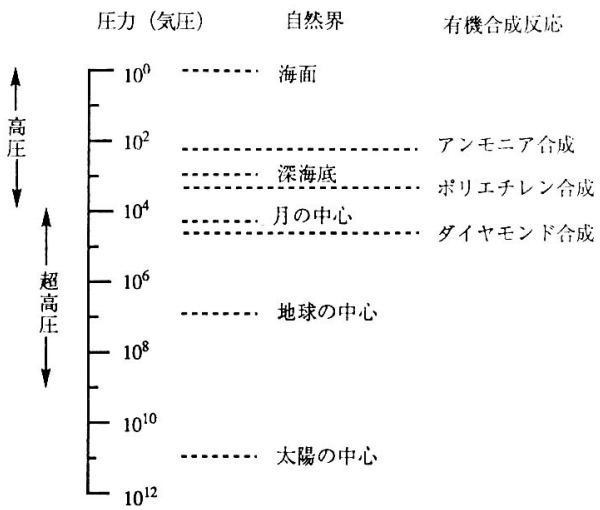

図 1 自然界の圧力と高圧下の有機合成反応例

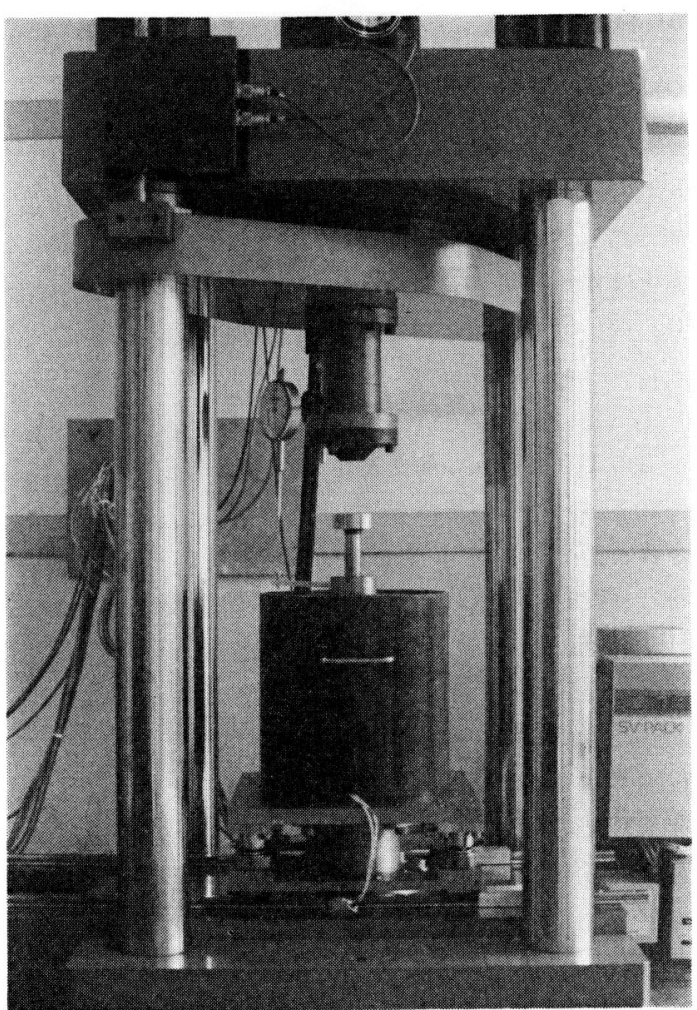

図 2 超高圧化学反応装置

じて反応チューブ内部に到達させ超高压下での化学反応 を起こさせる(図 4).

\section{高圧および反応溶媒}

有機化学反応への高圧の効果は数千気圧から現われる 場合もあるが，一般には圧力は高いほうがよく，1万〜

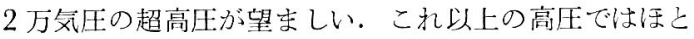

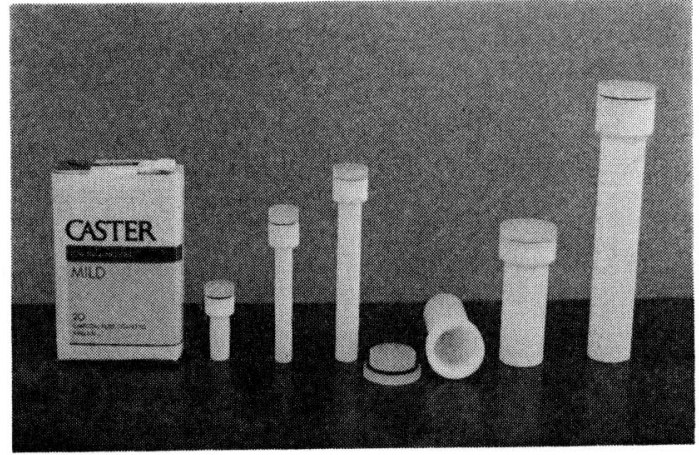

図 3 テフロン製反応チューブ

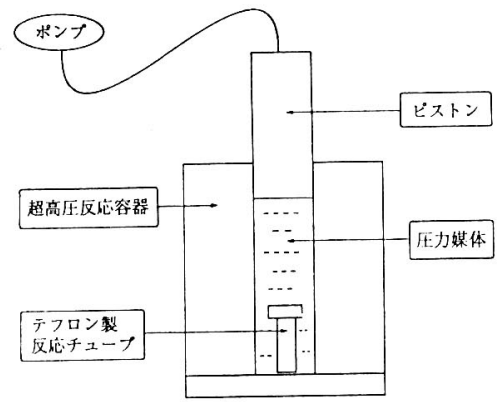

図 4 超高圧化学反応装置一簡略断面図

表 1 溶媒の凝固点と圧力の関係

\begin{tabular}{lrr}
\hline & \multicolumn{2}{c}{ 凝固点 $\left({ }^{\circ} \mathrm{C}\right)$} \\
\cline { 2 - 3 } 溶 媒 & 1 気圧下 & 高気圧下(気压) \\
\hline アセトン & -95 & $20(8000)$ \\
ベンゼン & 6 & $33(1000)$ \\
クロロホルム & -61 & $-45(1000)$ \\
エチルアセテート & -84 & $25(12,100)$ \\
エタノール & -117 & $-108(1000)$ \\
エーテル & -116 & $35(12,000)$ \\
メタノール & -98 & $25(30,000)$ \\
ジロルメタン & -97 & $-85(1000)$ \\
トルエン & -95 & $30(9600)$ \\
水 & 0 & $-9(1000)$ \\
\hline
\end{tabular}

んどの有機溶媒は固化する。玄なわち，有機溶媒は一般 に超高压下で疑固点が上昇し，固化する場合があるので 反応に使用する溶媒の選択は重要である。たと光ば，ア セトン (常圧下の凝固点, $-95^{\circ} \mathrm{C}$ ) は 8000 気圧下では $20^{\circ} \mathrm{C}$ で固化する。.またベンゼンは 1000 気圧下で疑固 点は $33^{\circ} \mathrm{C}$ となり, 超高圧下では固化するので反応溶媒 としては不適当で古る。有機浴媒の凝固点之圧力の関係 を表1に示した。 
表 2 活性化体積 $\left(\Delta V^{*}\right)$ と反応速度の関係 $\left(25^{\circ} \mathrm{C}\right)$

\begin{tabular}{ccccc}
\hline & \multicolumn{3}{c}{$k p / k i$} \\
\cline { 2 - 5 } & 5000 気圧 & 10,000 気圧 & 15,000 気圧 & 20,000 気圧 \\
\hline-10 & 7.5 & 57 & 430 & 3200 \\
-20 & 57 & 3200 & $1.8 \times 10^{5}$ & $1.0 \times 10^{7}$ \\
-30 & 430 & $1.8 \times 10^{5}$ & $7.7 \times 10^{7}$ & $3.3 \times 10^{10}$ \\
\hline
\end{tabular}

$k p:$ 高圧下での速度定数, $k i$ : 常圧下での速度定数.

表 3 負の活性化体積をもつ反応

反応名
Diels-Alder 反応
Michael 付加

\section{超高圧化学反応}

化学反応に対する圧力と反応速度との関係は，次式で 表わされる。

$$
\delta \ln k / \delta p=-\Delta V^{\neq} / R T
$$

ここで $k$ は反応速度定数, $p$ は圧力, $T$ は温度, $R$ は気体定数であり， $\Delta V^{\neq}$は活性化体積である. 活性化 体積 $\Delta V^{\ddagger}$ は遷移状態の体積之原系の体積之の差を表わ し，体積の減少する反応では $\Delta V^{\neq}$は負となり，圧力の 増大と共に反応速度が増加する。すなわち, 遷移状態で 体積の減少が大きければその反応は加圧によって加速さ れることになる．活性化体積と圧力による反応速度との 関係を表 2 に示す. 活性化体積が小さいほど，かつ圧力 が高いほど反応が加速されることが明らかである、たと えば，活性化体積が $-30 \mathrm{~cm}^{3} / \mathrm{mol}$ の反応は， 20,000 気圧下では常圧の $10^{10}$ 倍にも加速される.

このように活性化体積の減少する反応として次のよう な反応が知られている．i）反応で分子の数が減少する 反応，ii）環状遷移状態をへる反応，iii）ダイポール遷 移状態をへる反応，iv) 立体障害のある反応.すなわち, これらの反応に高圧の効果は顕著に現われることを意味 している。このような負の活性化体積を有する代表的反 応とその活性化体積を表 3 に示した.

ついで，超高圧反応の幾つかの例を紹介する.

\section{Diels-Alder 型反応}

超高圧が有機合成にきわめて有効であることを有機合 成化学者に知らしめた報告の一つは, Dauben らによ る超高圧下の Diels-Alder 反応をもちいた昆虫誘引物 質カンタリジンの合成であった ${ }^{2)}$. 逆合成的にはフラン とカルボン酸無水物の Diels-Alder 反応で合成できる と考えられるが，この反応は常圧では進行不可能で，実 際の合成は十数行程をへる合成で達成されていた，超高 圧はこの反応をきわめて速やかに進行させカンタリジン の簡単な合成を可能とした。すなおち，フランと不飽和 カルボン酸無水物を $7 \mathrm{Kbar}$ 下, 室温 6 時間反応させ付 加体を得, ついで Raney Ni 還元することによりカン タリジンを 2 行程で合成することができた (式 1$)$. 一般 に分子間 Diels-Alder 反応は加圧により速やかに進行 することが知られており，その報告例はきわめて多 い. 沖縄産海綿より単離され強い抗腫䝧活性を有する Manzamine A の合成研究に 理研の超高圧反応装置が 利用された ${ }^{3)}$. 常圧下では加熱あるいはルイス酸触媒存 在下でも低收率であった Diels-Alder 反応が超高圧下 では加熱も, 触媒も必要なく高収率で進行し, 重要合成 中間体を得ることができた (式 2).

超高圧反応は単に高圧をかけるだけの比較的穞やかな 反応条件であり，不安定な原料あるいは生成物でも有効 に使用することができる．したがって，原料が分解する 
などの反応もきわめて少なく，望みの反応を進行させる 利点を有している.
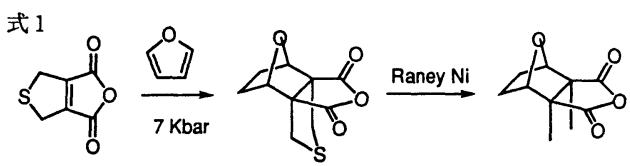

Cantharidin

式2
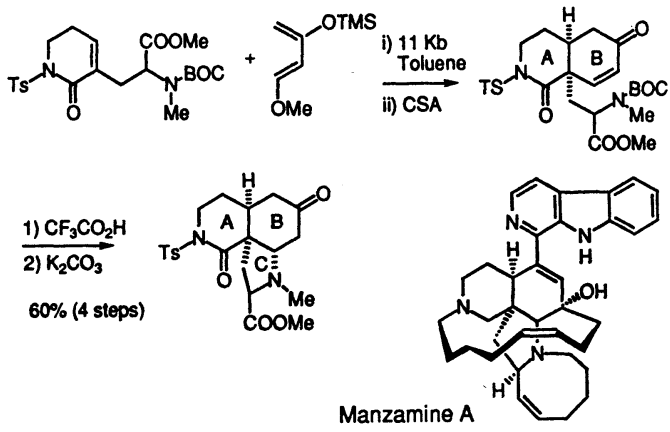

\section{2. 付加反応}

一般に付加反応には超高圧の効果が顕著に現われる.

反応性の低い，あるいは立体障害のあるケトンへの Wittig 反応 ${ }^{4,5)}$, オキシム形成等が超高圧下では速やか に進行する ${ }^{6)}$ (式 3). 常圧では起きないニトリルの 3 量 環化体を超高圧により得ることができ, Mannich 反応 も容易に進行する. 水素化ブチルスズによるケトンの還 元は超高圧下においてはラジカル開始剤やルイス酸なし でも進行する.

式3<smiles>CC1CCCC(C)(C)C1=O</smiles>

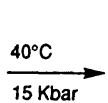<smiles>C=C1C(C)CCCC1(C)C</smiles>

55\%（常圧, THF遗流；2\%）

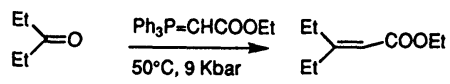

$70 \%$ （常圧，xylene曼流；15\%)
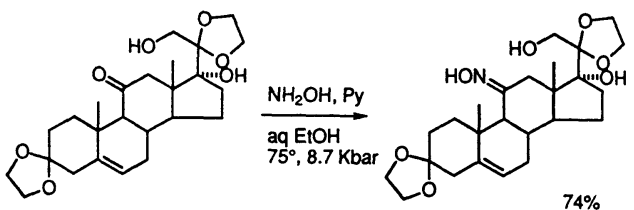

$74 \%$

\section{3. 共役付加反応}

$\alpha, \beta$-不飽和ケトンに対するシリルケテンアセタール の共役付加は高高い置換基を有する化合物でも速やかに
進行し7)(式 4), これらの反応は強い抗腫煌活性を有す る Quassinoid の合成研究に用いられている. 超高圧は $\alpha, \beta$-不飽和ケトンへのニトロアルカン, チオールの Michael 付加反応にも有効である.アクリレートの塩基 存在下のカルボニルへの付加は $1 \sim 5 \mathrm{Kbar}$ 加圧下で容 易に進行する. 不斉 Michael 反応として, $\alpha, \beta$-不飽和 エステルヘの 1 級アミンの立体選択的な付加が報告され ている.たとえば，(ー)ーメントールから誘導したクロ トン酸エステルヘのベンズヒドリルアミンの共役付加反 応が検討され，Xがナフチル基のとき $99 \%$ の高いジア ステレオ選択性が得られている ${ }^{8)}$ (式 5). このような超 高圧下での不斉合成反応は今後の発展が期待できる.

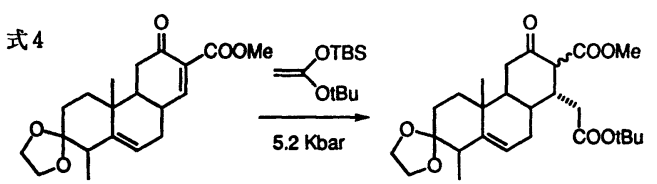

式5
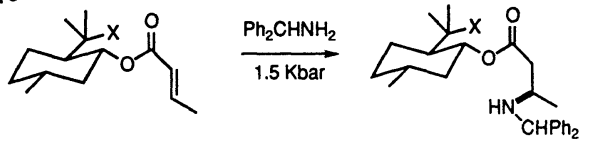

\section{4. アルドール型反応}

シリルエノールエーテルとアルデヒドとのアルドール 反応は，通常はルイス酸が必要であるが，超高圧下では 無触媒，中性条件下で反応が進行する ${ }^{9)}$ (式 6). その生 成物の選択性はルイス 酸使用のときとは逆転し(常圧, $\mathrm{TiCl}_{4}, 25 / 75$; 超高圧, 75/25), 超高圧下での反応はボー 卜型の遷移状態をへて進行すると考えられる. ケテン シリルアセタールとアルデヒドの反応も超高圧下, 中性 条件で進行し，アリルスズのアルデヒドへの付加も室温 $10 \mathrm{Kbar}$ で進行した，超高圧下の立体選択的反応に関 する研究は新しい展開が期待できる.

式 6

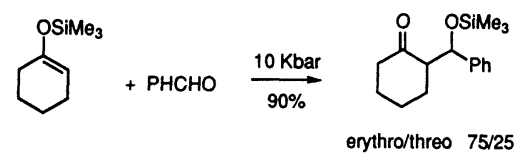

われわれは紅海産海綿から単離され強い抗腫瘍性を有 する複雑な化学構造の 44 員環マクロリド Swinholide A の合成研究を行なっているが，その合成中間体の合成 に超高圧を利用した ${ }^{10)}$. すなわち，トリエチルアミン 中， 2 等量のアルデヒド 1 に 1 等量のニトロメタンを常 
圧下反応させたが求める 2 は低収率であった，そこでこ の反応を超高圧下で行なうと，ダブルニトロアルドール 反応が一挙に起き，収率 $89 \%$ で 2 を得ることができ， さらに重要中間体 3 への変換に成功した (式 7). 理研超 高圧装置を用いれば 2 を一度に $100 \mathrm{~g}$ 以上得ることが 可能であり，天然物合成に十分量を供給できる.このよ うに, 複雑な天然物合成への超高圧反応の有用性は今後 ますます增大するものと考えられる。
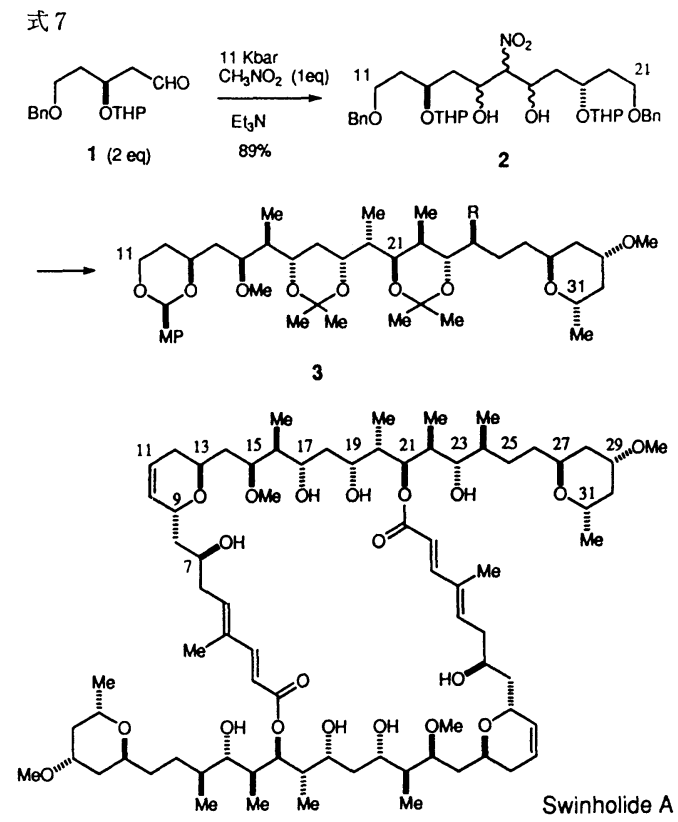

\section{5. 置換反応}

芳香環への親電子置換反応, フェノールのアルキル 化，エーテル化が報告されている. 脱離基へのアミンの 付加は立体化学の反転を伴って速やかに進行する.

\section{4 級 塩 化}

アミン，ピリジンの 4 級塩化は容易に達成できる.

\section{7. 保護基の導入}

多段階の天然物合成においては，適当な保護基を選択 し，いかに合成経路に組み込むかが重要な問題の一つで ある，超高圧下では，立体障害のある系でのケトンのケ タール化，アルコールのシリル化，アセチル化などの保 護基の導入が可能である．化合物の構造が複雑になるほ
ぞ保護基の導入は難しくなるので超高圧下での保護基導 入は有用化合物の合成において重要な手段となる.

おわりに

これまで数多くの超高圧下の反応が検討されている が，そのほとんどは化学反応的見地から研究が行なわれ ていた。 それらの研究成果を基盤として，超高圧反応は 今や実用的段階に入ったといえる. 今後さらに，有機合 成化学的見地からのより一層の検討とその高度化が望ま れる。

以上述べてきたように, 超高圧下での化学反応におい ては, 反応時間の短縮, 収率の飛踓的向上, 熱, 触媒等 に敏感な不安定化合物の合成，これまで合成困難であっ た新しい反応剂, 目標化合物の合成，短縮合成ルートの 開拓，新規反応の開発，有機合成反応への新しい概念の 提出など多くの可能性があり，この分野の研究がますま す大きく発展することを期待している。

\section{引用 女 献}

1) 化学総説, No. 22 超高圧と化学, 学会出版セン 夕ー, 1979; K. Matsumoto, A. Sera \& T. Uchida: Synthesis 1, 999(1985); 上原忠夫, 斉藤研一, 山 本嘉則: 有合化 47, 321 (1989); 片桐信弥, 金子主 税：現代化学，1月，30(1990)

2) W. G. Dauben, C. R. Kessel \& K. H. Takemura: J. Am. Chem. Soc. 102, 6893 (1980)

3) Y. Torisawa, M. Nakagawa, H. Arai, T. Hino, T. Nakata \& T. Oishi: Tetrahedron Lett. 31, 3195 (1990)

4) W. G. Dauben \& J. J. Takasugi: Tetrahedron Lett. 28, 4377 (1987)

5) N. S. Isaacs \& G. N. El-Din: Tetrahedron Lett. 28, 2191 (1987)

6) W. H. Jones, E. W. Tristram \& W. F. Benning: J. Am. Chem. Soc. 81, 2151 (1959)

7) C. H. Heathcock, C. Mahaim, M. F. Schlecht \& T. Utawant: J. Org. Chem. 49, 3246 (1984)

8) J. d'Angelo \& J. Maddaluno: J. Am. Chem. Soc. 108, 8112 (1986)

9) Y. Yamamoto, K. Maruyama \& K. Matsumoto: J. Am. Chem. Soc. 105, 6963 (1983)

10) 中田 忠, 小松俊哉, 長澤和夫, 大石 武: 第 34 回天然有機化合物討論会講演要旨集, 東京, p. 174,1992 